\title{
Genetic Analysis of Earliness and Lint Yield under Normal and Late Sowing Dates in Egyptian Cotton
}

\author{
Ezzat E. Mahdy, Atif Abo-Elwafa, G.H. Abd EI-Zaher*, Mohammed A. Sayed ${ }^{\#}$ \\ and Mohamed G. Hosein* \\ Agronomy Department, Faculty of Agriculture, Assiut University, Assiut and *Cotton \\ Research Institute, Agricultural Research Center (ARC), Giza, Egypt.
}

\begin{abstract}
THE PRESENT work was conducted to study the effects of late planting on the performance of Egyptian cottons, sensitivity to environments and gene action controlled earliness, lint yield/plant, lint \% and lint index. A half diallel crosses of eight Egyptian cottons varieties were evaluated under normal and late plantings. The reduction \% in lint yield/plant was 23.21 and $23.87 \%$ for the parents and $\mathrm{F}_{1}$ hybrids; respectively. The results of stress susceptibility index of LY/P indicated that six parents were tolerant for LY/P to late planting. Sixteen out of the 28 hybrids showed tolerance in LY/P to late planting. The diallel analysis revealed significant ( $\mathrm{p} \leq$ 0.01 ) items; " a" and " $b$ ", indicating that both additive and dominance effects of genes were involved in the inheritance of the five studied traits. The genetic parameter indicating that ' $\mathrm{H}_{1}$ ", tended to be more than the additive parameter ' $\mathrm{D}$ ' ' under late planting. The regression analysis of $\mathrm{Wr} / \mathrm{Vr}$ indicated the presence of non-allelic interaction in the inheritance of lint yield/plant under late planting. However, the additive-dominance model was adequate in the inheritance of days to first flower under normal and late plantings. The ' $\mathrm{b}_{2}$," item and $\mathrm{KD} / \mathrm{KR}$ indicated unequal distribution of dominance and recessive genes in the parents for all traits. The nonadditive effects of genes were reflected in the departure of narrow form broad sense heritability. Therefore, pedigree and recurrent selection breeding methods could be effective to isolate lines adapted to late planting.
\end{abstract}

Keywords: Egyptian cotton, Earliness, Lint yield, Late planting, Diallel analysis.

\section{Introduction}

The Egyptian cottons (Gossypium barbadense L.) of long and extra-long staple have a good reputation worldwide for their good processing fiber properties. Currently, the area planted by cotton and yield per unit area is decreasing year after year. This is attributed to two main causes: (1) The producers delay sowing date for a month after March 30 (the recommended date for sowing) to get complete winter crop especially wheat before cotton, (2) The Egyptian cotton cultivars were bred as a full season crop (180 days) grown from mid-March to mid-September. Consequently, the Egyptian cotton cultivars can't tolerate the environmental stress of late sowing and often result in progressively decreasing yield. Many reports emphasized the adverse effects of late sowing on yield and fiber properties, and may mask any genetic improvement in cotton (Bauer et al., 1998; Bange \& Milroy, 2004; Bange et al., 2008 and Pettigrew \& Meredith, 2009). The lack of understanding the effects of late sowing on genetics of yield and fiber properties of cotton is a great obstacle in improving new strains of cotton adapted to short season production. Diallel analysis as developed by Hayman (1954 and 1958), Jinks (1956) and Jinks \& Hayman (1953) provides sufficient information to identify superior parents and crosses for different traits. Several researchers (Luckett, 1989; Khan et al., 1995; Iqbal \& Khan, 1996; Esmail et al., 1999; Mukhtar et al., 2000; Nadeem \& Azhar, 2004; Basal \& Turgut, 2005; Mohamed et al., 2009; Imran et al., 2012; Kumar et al., 2013; Raza et al., 2013; Simon et al., 2013; Soomro et al., 2006; Waqar et al., 2015 and Memon et al., 2016) pointed to the importance of genetic studies of the materials before selecting the desirable plant. Lasheen et al. (2003), Azhar \& Khan (2005) and Abd El-Bary et al. (2008) found that the general combining ability (GCA) variances were greater

"Corresponding author email: mohamed.sayed5@agr.au.edu.eg

DOI: 10.21608/agro.2018.1727.1077

C2018 National Information and Documentation Center (NIDOC) 
than specific combining ability (SCA) variances, revealing the predominance of additive gene effects. Patil et al. (2005) reported inadequacy of the additive-dominance model and the presence of non-allelic gene interaction. The three types of epistasis differed from cross to cross (Darweesh, 2006; Abd-El-Haleem et al., 2010 and El-Refaey et al., 2013). Laxman et al. (2003) revealed that the components of genetic variance indicated predominance of dominance $\times$ dominance type of epistatic interaction followed by additive $x$ dominance, besides equally important role of dominance, additive and additive $\times$ additive type of gene actions were found. Hajazi et al. (2014) stated that the estimates of narrow senses heritability were moderate for node number of the $1^{\text {st }}$ sympodial branch $(45 \%)$ and stated that the additive component was less than the values of the dominance components $\mathrm{H}_{1}$ and $\mathrm{H}_{2}$ for days to flowering $\left(\mathrm{H}_{1}=32.64, \mathrm{H}_{2}=31.39\right)$ and node number for $1^{\text {st }}$ sympodial branch $\left(\mathrm{H}_{1}=4.27, \mathrm{H}_{2}=\right.$ 4.04) showing the predominance of non-additive genetic effects. Abd El-Bary (2003) found that epistatic variances; additive by additive genetic variances $\left(\sigma_{\mathrm{AA}}^{2}\right)$ showed positive values for all studied traits except fiber fineness. Additive by dominance genetic variances $\left(\sigma_{\mathrm{AD}}^{2}\right)$ played the major role in controlling the inheritance of the studied characters of the triallel crosses; therefore, recurrent selection might be useful in improving the studied characters of the triallel crosses in the breeding programs. The results also demonstrated that the calculated values of heritability in narrow sense ranged from $39.43 \%$ to $55.19 \%$ for seed cotton yield/plant and fiber fineness, respectively. Raza et al. (2013) investigated the inheritance pattern of some metric plant traits in a complete diallel design. The over-dominance effects were mainly contributed for number of bolls per plant. Partial dominance was involved for number of sympodial branches, boll weight, yield of seed cotton and lint percentage. The current manuscript represents a study of the effects of late sowing date on the performance, sensitivity to environment, to obtain detailed information concerning the genetic control of earliness, lint yield and its components of eight parents diallel crosses of Egyptian cotton cultivars under normal and late sowing dates for two seasons.

\section{Materials and Methods}

\section{Plant materials}

The present study was carried out at Shandaweel Res. Stn., Sohag, Cotton Res. Inst., ARC, during the two summer seasons of 2015 and 2016. The basic materials were eight Egyptian cotton varieties belong to $G$. barbadense L. Pure selfed seeds of these varieties were obtained from Cotton Research Institute, Agricultural Research Center at Giza, Egypt. The name, pedigree and the main characteristics of these varieties are presented in Table 1.

TABLE 1. The name, pedigree and the main characteristics of the eight cotton varieties used in the study.

\begin{tabular}{|c|c|c|}
\hline Genotypes & Pedigree & Characteristics \\
\hline Giza 95 & $\begin{array}{l}{[(\mathrm{G} .83 \times(\mathrm{G} .75 \times 5844)) \times} \\
\text { G.80] }\end{array}$ & $\begin{array}{l}\text { A new long staple cotton variety, characterized by high yielding } \\
\text { ability, high lint percentage, normal maturity and heat tolerance } \\
\text { (cultivated). }\end{array}$ \\
\hline Giza 92 & G84(G74 x G68) & An extra-long staple variety, (cultivated). \\
\hline Giza 90 & Giza83× Dandara & $\begin{array}{l}\text { Long staple variety for upper Egypt, high yield and lint } \\
\text { percentage (cultivated). }\end{array}$ \\
\hline Giza $90 \times$ Aus & Giza90 $\times$ Australian & Characterized by high yielding and earliness (cultivated). \\
\hline Giza 87 & (G.77G.45A) & An extra-long staple (cultivated). \\
\hline Giza 86 & (G.77G.45B) & Long staple variety, characterized by high yield \\
\hline Giza 80 & G. $66 \mathrm{G} .73$ & $\begin{array}{l}\text { Long staple variety. It is high yield and lint percentage } \\
\text { (cultivated). }\end{array}$ \\
\hline Giza 45 & G. 7 G. 28 & An extra-long staple variety, (obsolete). \\
\hline
\end{tabular}




\section{Experimental design and field conditions}

In the first season (2015), the eight varieties were crossed in $8 \times 8$ diallel mating design. In the second season (2016), the eight parents with their $28 \mathrm{~F} 1$ 's crosses were evaluated in the two planting dates, i. e., normal on the $29^{\text {th }}$ of March and $1^{\text {st }}$ May in a randomized complete blocks design with three replications in the two separate experiment. Each plot consisted of one row, fourmeter-long, $0.6 \mathrm{~m}$ apart and $40 \mathrm{~cm}$ between hills within a row. After full emergence, seedlings were thinned to one plant per hill. All cultural practices were followed throughout the growing season as usually done with ordinary cotton cultivation. Data were recorded for: 1- Lint yield/plant; g (LY/P); 2- Lint percentage (LP); 3- Lint index; 4- Seed index; g (SI); 5- Earliness index (EI) (weight of the first pick/weight of the two picks of seed cotton yield) and 6- Days to first flower (DFF).

\section{Statistical analyses}

The analysis of variance was performed in a randomized complete block design (RCBD) as outlined by Steel \& Torrie (1980). Mean comparisons were calculated using revised L.S.D, where R L S D $=\left(\mathrm{t}^{\prime}\right){ }_{\alpha} * \sqrt{ }(2 \mathrm{MSE} / \mathrm{r})$ as outlined by El- Rawi \& Khalafalla (1980). Stress susceptibility index (SSI) was calculated for LY/P according to the method of Fischer \& Maurer (1978):

Yield of individual genotype was determined under stress (Yl) (late planting) and favorable (Ye) (normal planting) conditions. Average yield of all genotypes under late (Xl) and normal conditions (Xe) were used to calculate stress intensity (D) as:

$$
\mathrm{D}=1-\mathrm{Xl} / \mathrm{Xe}
$$

The mean stress susceptibility index (S) of individual genotype was calculated as:

$$
\mathrm{SSI}=(1-\mathrm{Y} 1 / \mathrm{Ye}) / \mathrm{D}
$$

Genotypes with average susceptibility to stress have «SSI» value of 1.0 , values less than 1.0 indicate less susceptibility and great resistance to drought. Meanwhile, a value of $\mathrm{SSI}=0.0$ indicates maximum possible stress resistance (no effect of stress on yield).

The diallel analysis was performed as outlined by Hayman (1954) and described by Mather \& Jinks (1971)

\section{Results and Discussion}

Means and reduction\%

Mean lint yield/plant of the parental lines under normal planting ranged from $21.50 \mathrm{~g}$ (G.87 extralong) to $50.63 \mathrm{~g}$ (Giza $90 \times$ Aus) with an average of $36.70 \mathrm{~g}$, and from $17.17 \mathrm{~g}$ to $40.30 \mathrm{~g}$ with an average of $28.18 \mathrm{~g}$ for the respective parents under late planting (Table 2). The reduction \% in lint yield/plant was large and reached $23.21 \%$ for the parents and $23.87 \%$ for the $\mathrm{F}_{1}$ - hybrids. These results are in line with those reported by Bange \& Milroy (2004), Boquet \& Clawson (2009), Pettigrew \& Meredith (2009) and Abdalla $(2013$, 2014). They pointed to the adverse effects of climatic conditions and late sowing on yield and fiber properties. The results of stress susceptibility index of LY/P indicated that six parents (G.90, G.90 $\times$ Aus, G.87, G.86, G.80 and G.45) were tolerant to late planting. Sixteen out of the 28 hybrids showed tolerance in $\mathrm{LY} / \mathrm{P}$ to late planting. The tolerant hybrids originated from one or both parents were tolerant. These hybrids are promising to isolate new lines tolerant in SCY/P to late planting.

The reduction in lint \% was small and scored $6.46 \%$ for the parents and $6.68 \%$ for $\mathrm{F}_{1}$ - hybrids under normal planting, lint $\%$ of the parents ranged from 32.43 (G.87) to 41.28 (G.95) with an average of $37.75 \%$, and from 30.50 (G.87) to 38.07 (G.90 × Aus) with an average of $35.31 \%$ under late planting. Generally, three extra-long staple varieties Giza 92, Giza 87 and Giza 45 were lower in magnitudes than the long staple for yields and lint $\%$. The $\mathrm{F}_{1}$ - hybrids mean performance under normal planting ranged from 32.63 to 40.49 with an average of $37.53 \%$ and from 31.44 to 37.58 with an average of $35.02 \%$ under late planting for lint percentage.

Mean lint index of the parental lines under normal planting ranged from 5.29 for G.45 to 7.42 for G.95 with an average of $6.13 \mathrm{~g}$ and from $5.46 \mathrm{~g}$ for G.45 to $7.56 \mathrm{~g}$ for G.90 × Aus with an average of $6.46 \mathrm{~g}$ under late plating. Mean lint index of the $\mathrm{F}_{1}$ - hybrids under normal planting ranged from $5.05 \mathrm{~g}$ for G.92 $\times$ G.87 to $7.80 \mathrm{~g}$ for $\mathrm{G} .95 \times$ "G.90 $\times$ Aus" with an average of $6.29 \mathrm{~g}$ and from $5.34 \mathrm{~g}$ to $7.63 \mathrm{~g}$ with an average of $6.23 \mathrm{~g}$ for the above respective hybrids under late planting. The reduction $\%$ was small in the $\mathrm{F}_{1}$ - hybrids $(0.95 \%)$ and negative $(-5.38 \%)$ for the parents. This is mainly due to that the reduction in lint yield was more than that in seed cotton yield (not included). 
TABLE 2. Mean lint yield/plant, SSI, lint $\%$ and lint index of $8 \times 8$ diallel crosses evaluated under normal (D1) and late (D2) sowing dates in 2016.

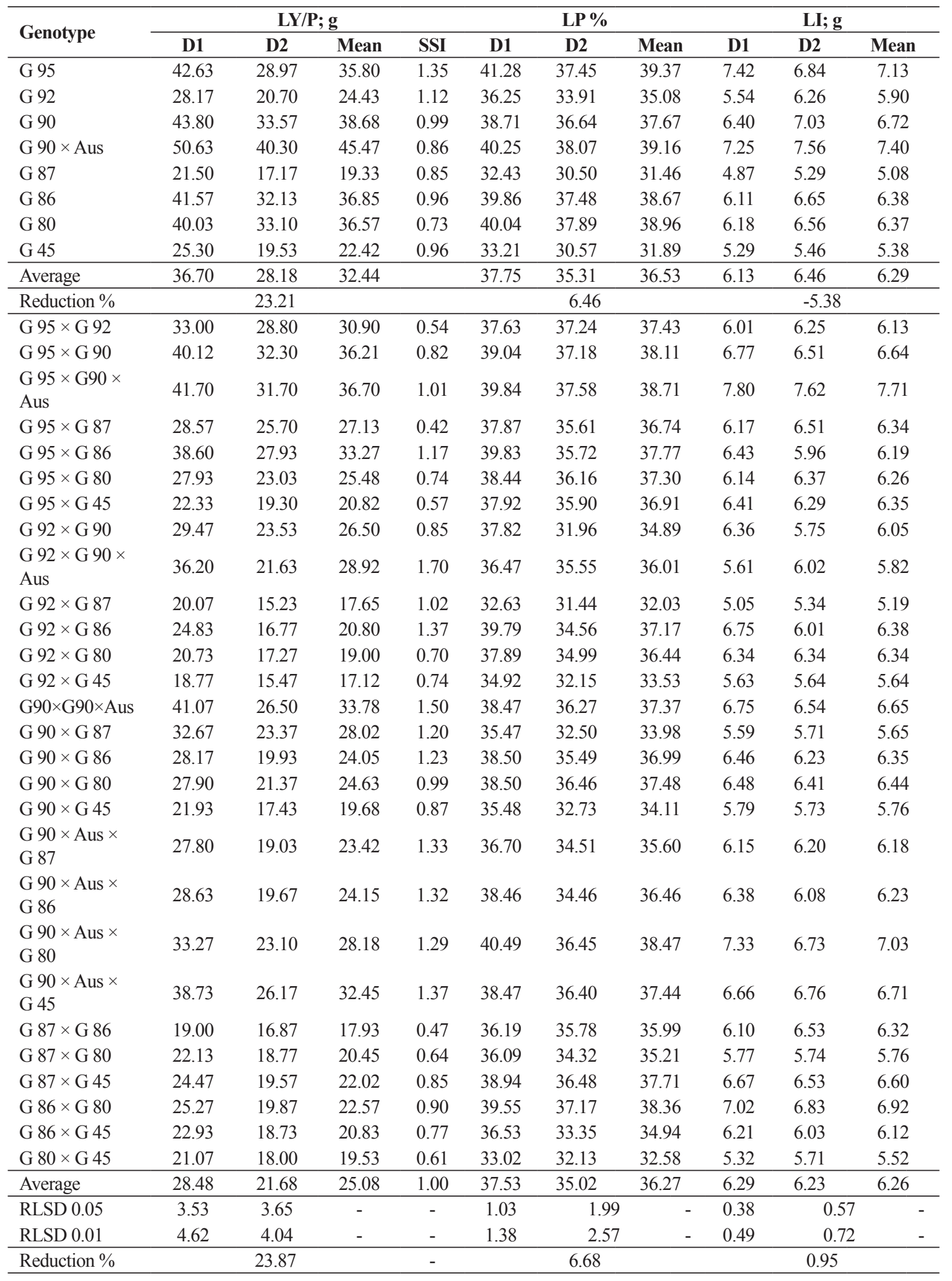

SSI; stress susceptibility index. 
Mean days to first flower (Table 3) of the parental lines under normal planting ranged from 66.67 days for G.90 (the earliest parent) to 79.00 days for G.90× Aus with an average of 72.79 days, and from 66.33 days to 75.33 days with an average of 72.17 days for the same respective parents under late planting. Mean days to first flower under normal planting of the $\mathrm{F}_{1}$ - hybrids ranged from 69.0 days to 75.33 days with an average of 73.35 days and from 68.0 days to 74.0 days with an average 72.3 days under late planting. The reduction $\%$ in days to first flower of the parental lines of these materials was small $(0.85 \%)$, however, it reached $9.47 \%$ in the $\mathrm{F}_{1}$ - hybrids indicated that late planting shortened the period of vegetative growth. Abdalla (2014) indicated that late planting increased earliness.

The over- all means of earliness index (Table 3) ranged from 59.26 for G. 45 to 80.32 for G. 90 with an average of $70.08 \%$ for the parents. The overall means of earliness index of the $\mathrm{F}_{1}$ - hybrids ranged from 63.11 to 78.96 with an average of $67.67 \%$. The reduction $\%$ was very small and negligible. This mainly due to that the first pick is done visually when the open bolls of the most entries reached about $60 \%$. Earliness index is the most favorable method in estimating earliness for cotton breeding program. G. 90 flowered normal and showed the highest earliness index, indicating that G. 90 flowered normal and gave most of its yield in few weeks. This indicated that G. 90 has a leptokurtic flowering curve. The shape of the flowering curve is very clear for G. $90 \times$ Aus, which flowered late (the latest variety) and showed high earliness index. This means that G. $90 \times$ Aus gave most of its flowers in few weeks and showed leptokurtic curve of flowering. The hybrid G. $90 \times \mathrm{G}$ 92 flowered normal and showed low earliness index indicating platykurtic flowering curve.

\section{The diallel analysis of variance}

The analysis variance (Tables 4 and 5) indicated significant $(\mathrm{p} \leq 0.01)$ differences among genotypes (parents and crosses) for lint yield/plant, lint \%, lint index, days to first flower and earliness index. Therefore, the diallel analysis was performed. The analysis of variance was done for the parents, $\mathrm{F}_{1}$ hybrids and "parents $+\mathrm{F}_{1}$ - hybrids" separately under the two planting dates (not included). A comparison of the block interaction (exp. error) for the parental families and for the $\mathrm{F}_{1}$ - hybrids of the diallel set showed insignificant differences between them (with 14 and 54 degrees of freedom). Therefore, $\mathrm{E}_{\mathrm{p}}=\mathrm{E}_{\mathrm{F} 1}$ and both equal the block interaction mean squares $(\mathrm{Bt})$ for the 36 replicated families of the diallel (Mather \& Jinks, 1971). The diallel analysis of variance (Tables 4 and 5) showed significant $(p \leq 0.01)$ mean squares of the item "a" and "b", indicating that both additive and dominant effects of genes were involved in the inheritance of the above traits.

With regard to three items (" $b_{1}, b_{2}$ and $b_{3}$ ") of non-additive component (b), results revealed that, the " $b_{1}$ " item mean square was significant for lint yield/plant, lint index and earliness index under both planting dates, and lint $\%$ and days to first flower under late planting condition. The "b, item mean squares tests the mean deviation of the $\mathrm{F}_{1}$ - hybrids from the mid - parental value with one degree of freedom. Significant " $b_{1}$ " indicates directional dominance. The " $b_{2}$ " item was significant for the five studied traits except for lint $\%$ and earliness index under normal planting. Significant " $b_{2}$ " item indicating asymmetrical distribution of dominance and recessive genes among the parents. The " $b_{3}$ " item mean square was significant $(p \leq 0.01)$ for all traits. The " $b_{3}$ " item test the part of dominance deviation that it is unique to each $\mathrm{F}_{1}$ - hybrid, and it is a measure of specific combining ability, similar results were reported by Mahdy (1982 a, b) and Mohamed et al (2009).

\section{The interpretation of $\mathrm{Wr} / \mathrm{Vr}$ graph}

The graphical analysis of lint yield/plant (Fig. 1 and 2) indicated that the regression coefficient of $\mathrm{Wr} / \mathrm{Vr}$ under normal planting did not differ from unity, but, significantly differ from zero indicating the adequacy of additive dominance model to explain inheritance pattern of this trait (Table 4). Furthermore, the mean squares of $\mathrm{Wr}+\mathrm{Vr}$ was significant, and $\mathrm{Wr}-\mathrm{Vr}$ was not, indicating absence of epistatic effects of genes. However, under late planting the regression coefficient was significant $(\mathrm{p} \leq 0.01)$ from unity and zero, indicating the presence of non- allelic gene interaction despite insignificant $\mathrm{Wr}-\mathrm{Vr}$ mean squares. The intercept of the regression line was positive under the two planting dates, indicating partial dominance. However, it could be considered complete dominance for two reasons. First, the Wr and Vr must be corrected to the environmental component (Mather \& Jinks, 1971). Second, the intercept under normal planting was 7.4321 and the maximum $\mathrm{Wr}$ and Vr (G.95) was about 60. Under late planting, G. $90 \times$ Aus recorded wr of 35 and $\mathrm{vr}$ of 50 , and intercept was 5.1253 (near the origin). The distribution of the parents around the 
TABLE 3. Mean earliness index and days of first flower \% of eight Egyptian cotton varieties and their crosses evaluated under normal ( D1) and late (D2) sowing dates in 2016.

\begin{tabular}{|c|c|c|c|c|c|c|}
\hline \multirow{2}{*}{ Genotype } & \multicolumn{3}{|c|}{ EI \% } & \multicolumn{3}{|l|}{ DFF } \\
\hline & D1 & D2 & Mean & D1 & D2 & Mean \\
\hline G 95 & 77.91 & 78.16 & 78.03 & 70.00 & 70.00 & 70.00 \\
\hline G 92 & 62.38 & 63.40 & 62.89 & 72.33 & 73.00 & 72.67 \\
\hline G 90 & 81.04 & 79.59 & 80.32 & 66.67 & 66.33 & 66.50 \\
\hline G $90 \times$ Aus & 79.79 & 79.78 & 79.78 & 79.00 & 75.33 & 77.17 \\
\hline G 87 & 60.14 & 61.70 & 60.92 & 73.67 & 71.67 & 72.67 \\
\hline G 86 & 61.08 & 60.18 & 60.63 & 74.00 & 74.00 & 74.00 \\
\hline G 80 & 78.57 & 79.06 & 78.82 & 72.67 & 74.00 & 73.33 \\
\hline G 45 & 58.84 & 59.68 & 59.26 & 74.00 & 73.00 & 73.50 \\
\hline Average & 69.97 & 70.19 & 70.08 & 72.79 & 72.17 & 72.48 \\
\hline Reduction \% & \multicolumn{3}{|c|}{-0.31} & \multicolumn{3}{|c|}{0.85} \\
\hline G $95 \times$ G 92 & 65.78 & 66.12 & 65.95 & 71.33 & 70.00 & 70.67 \\
\hline G $95 \times$ G 90 & 78.98 & 78.94 & 78.96 & 69.00 & 68.67 & 68.83 \\
\hline G $95 \times$ G $90 \times$ Aus & 76.38 & 77.36 & 76.87 & 74.00 & 71.00 & 72.50 \\
\hline G $95 \times$ G 87 & 70.49 & 71.37 & 70.93 & 74.00 & 72.00 & 73.00 \\
\hline G $95 \times$ G 86 & 67.50 & 68.08 & 67.79 & 73.67 & 73.00 & 73.33 \\
\hline G $95 \times$ G 80 & 72.46 & 71.61 & 72.04 & 70.67 & 70.00 & 70.33 \\
\hline G $95 \times$ G 45 & 66.74 & 66.40 & 66.57 & 73.33 & 73.00 & 73.17 \\
\hline G $92 \times$ G 90 & 67.37 & 66.53 & 66.95 & 70.67 & 68.00 & 69.33 \\
\hline G $92 \times$ G $90 \times$ Aus & 69.45 & 64.38 & 66.92 & 75.00 & 73.00 & 74.00 \\
\hline G $92 \times$ G 87 & 62.55 & 64.37 & 63.46 & 74.33 & 74.00 & 74.17 \\
\hline G $92 \times$ G 86 & 62.76 & 78.64 & 70.70 & 73.33 & 74.00 & 73.67 \\
\hline G $92 \times$ G 80 & 65.55 & 65.49 & 65.52 & 72.67 & 72.00 & 72.33 \\
\hline G $92 \times$ G 45 & 63.48 & 64.48 & 63.98 & 74.33 & 74.00 & 74.17 \\
\hline G $90 \times$ G $90 \times$ Aus & 78.18 & 74.31 & 76.24 & 72.00 & 72.33 & 72.17 \\
\hline $\mathrm{G} 90 \times \mathrm{G} 87$ & 64.91 & 62.91 & 63.91 & 74.00 & 73.33 & 73.67 \\
\hline G $90 \times$ G 86 & 65.59 & 65.09 & 65.34 & 74.67 & 72.67 & 73.67 \\
\hline G $90 \times$ G 80 & 73.20 & 64.81 & 69.00 & 72.00 & 70.33 & 71.17 \\
\hline $\mathrm{G} 90 \times \mathrm{G} 45$ & 64.13 & 72.80 & 68.47 & 74.00 & 74.00 & 74.00 \\
\hline G $90 \times$ Aus $\times$ G 87 & 64.02 & 62.20 & 63.11 & 75.00 & 74.00 & 74.50 \\
\hline G $90 \times$ Aus $\times$ G 86 & 65.61 & 66.56 & 66.08 & 75.00 & 73.00 & 74.00 \\
\hline G $90 \times$ Aus $\times$ G80 & 73.09 & 69.40 & 71.24 & 72.33 & 72.00 & 72.17 \\
\hline G $90 \times$ Aus $\times$ G 45 & 63.71 & 64.05 & 63.88 & 75.33 & 73.00 & 74.17 \\
\hline G $87 \times$ G 86 & 65.50 & 65.35 & 65.43 & 73.33 & 73.00 & 73.17 \\
\hline G $87 \times$ G 80 & 68.56 & 65.30 & 66.93 & 72.33 & 72.33 & 72.33 \\
\hline G $87 \times$ G 45 & 62.82 & 64.22 & 63.52 & 75.33 & 73.33 & 74.33 \\
\hline G $86 \times$ G 80 & 65.14 & 66.82 & 65.98 & 73.00 & 72.33 & 72.67 \\
\hline G $86 \times$ G 45 & 66.23 & 65.20 & 65.72 & 74.00 & 73.00 & 73.50 \\
\hline $\mathrm{G} 80 \times \mathrm{G} 45$ & 63.86 & 62.85 & 63.35 & 75.00 & 73.00 & 74.00 \\
\hline Average & 67.64 & 67.70 & 67.67 & 73.35 & 72.30 & 72.82 \\
\hline RLSD 0.05 & 7.20 & 7.10 & & 2.31 & 1.90 & \\
\hline RLSD 0.01 & 9.34 & 9.21 & & 3.03 & 2.43 & \\
\hline Reduction \% & & 2.97 & & & 9.47 & \\
\hline
\end{tabular}


TABLE 4. Mean squares of the diallel analysis for lint yield/plant, lint percentage and lint index at normal (D1) and late (D2) sowing dates .

\begin{tabular}{|c|c|c|c|c|c|c|c|}
\hline \multirow[b]{2}{*}{ Item } & \multicolumn{3}{|c|}{ LY/P; g } & \multicolumn{2}{|c|}{ LP \% } & \multicolumn{2}{|l|}{ LI; g } \\
\hline & df & D1 & D2 & D1 & D2 & D1 & D2 \\
\hline Blocks (b) & 2 & 4.008104 & 21.26583 & 1.672822 & 1.531302 & 0.251252 & 0.027979 \\
\hline Entries & 35 & $216.8416^{* *}$ & $113.7867 * *$ & $15.92469 * *$ & $13.90526^{* *}$ & $1.308846^{* *}$ & $0.894364 * *$ \\
\hline $\mathrm{a}$ & 7 & $1114.772 * *$ & $462.1697 * *$ & $73.0446 * *$ & $350.625 * *$ & $5.6319 * *$ & $3.4511 * *$ \\
\hline $\mathrm{b}$ & 28 & $143.7478 * *$ & $94.0669 * *$ & $12.8928 * *$ & $119.7232 * *$ & $1.2467 * *$ & $0.8996 * *$ \\
\hline b1 & 1 & $1421.445^{* *}$ & $888.2246^{* *}$ & 1.0170 & $130.4127 * *$ & $0.5290 * *$ & $1.0928 * *$ \\
\hline b2 & 7 & $88.8002 * *$ & $120.8664 * *$ & $4.8593 * *$ & $132.1518 * *$ & $0.3838 * *$ & $0.7484 * *$ \\
\hline b3 & 20 & $99.0945 * *$ & $44.9793 * *$ & $16.2983 * *$ & $114.8388^{* *}$ & $1.5846^{* *}$ & $0.9429 * *$ \\
\hline$a * b$ & 14 & 7.8437 & 7.6565 & 1.2399 & 35.7678 & 7.7113 & 0.2688 \\
\hline$b^{*} b$ & 56 & 10.5304 & 11.5406 & 0.7449 & 37.8214 & 0.1216 & 0.2444 \\
\hline $\mathrm{b} 1 * \mathrm{~b}$ & 2 & 1.9665 & 5.0265 & 1.1700 & 8.6760 & 0.1750 & 0.1419 \\
\hline $\mathrm{b} 2 * \mathrm{~b}$ & 14 & 13.3720 & 7.9977 & 0.7290 & 15.8669 & 0.1282 & 9.9581 \\
\hline $\mathrm{b} 3 * \mathrm{~b}$ & 40 & 9.9640 & 13.1063 & 0.7321 & 46.9627 & 0.1167 & 0.3003 \\
\hline Error (Bt) & 70 & 6.113532 & 6.131071 & 0.522341 & 1.67829 & 0.065915 & 0.13312 \\
\hline $\mathrm{r}(\mathrm{p}-, \mathrm{wr}+\mathrm{vr})$ & & $0.86574 * *$ & $0.91638 * *$ & -0.06207 & $0.89749 * *$ & 0.5754 & 0.45497 \\
\hline $\mathrm{Wr}+\mathrm{Vr}$ & & $*$ & $* *$ & $* *$ & ns & $* *$ & ns \\
\hline $\mathrm{Wr}-\mathrm{Vr}$ & & Ns & ns & $* *$ & $\mathrm{~ns}$ & ns & ns \\
\hline b from unity & & Ns & $* *$ & ns & ns & ns & ns \\
\hline $\mathrm{b}$ form 0.0 & & * & $* *$ & $\mathrm{~ns}$ & $\mathrm{~ns}$ & $*$ & ns \\
\hline
\end{tabular}

*, ** Significant at 0.05 and 0.01 levels of probability; respectively, b from unity and from zero is the significant deviation from unity and zero; respectively, $\mathrm{r}(\mathrm{p} ; \mathrm{wr}+\mathrm{vr})$ is the correlation between the performance of the parents and $\mathrm{Wr}+\mathrm{Vr}$, ns $=$ not significant.

regression line were consistent to large extent, and G. 45, G. 87, G. 92 have most dominant genes and located near the origin, while G. $90 \times$ Aus, G. 80 and G. 92 were located in the upper most of the regression line and have most of recessive genes. The correlation between $\mathrm{Wr}+$ $\mathrm{Vr}$ and mean performance of the parents was positive and significant (Table 4), indicating that the recessive genes controlling lint yield/ plant in this set of diallel were increasers. The graphic presentation of lint \% (Fig. 3 and 4) under normal planting condition showed that the regression coefficient was negative and was not significant from both of unity and zero, which indicates the presence of non-allelic interaction (Table 4). The mean squares of 
TABLE 5. Mean squares of the diallel analysis for earliness index and days to first flower at normal (D1) and late (D2) sowing dates.

\begin{tabular}{|c|c|c|c|c|c|}
\hline \multirow{2}{*}{ Item } & \multirow{2}{*}{ Df } & \multicolumn{2}{|c|}{ EI \% } & \multicolumn{2}{|c|}{ DFF } \\
\hline & & D1 & D2 & D1 & D2 \\
\hline Blocks (b) & 2 & 31.66676 & 4.548879 & 1.861111 & 0.009259 \\
\hline Entries & 35 & $114.9802 * *$ & $112.3013^{* *}$ & $13.54286^{* *}$ & $10.79656^{* *}$ \\
\hline $\mathrm{a}$ & 7 & $628.500^{* *}$ & $350.625^{* *}$ & $62.7142 * *$ & $62.7142 * *$ \\
\hline $\mathrm{b}$ & 28 & $50.7678 * *$ & $119.7232 * *$ & $8.5937^{* *}$ & $8.5937^{* *}$ \\
\hline b1 & 1 & $113.5531^{*}$ & $130.4127^{*}$ & 6.4352 & $6.4352 *$ \\
\hline b2 & 7 & 42.0558 & $132.1518^{* *}$ & $12.7321^{* *}$ & $12.7321 * *$ \\
\hline b3 & 20 & $50.6778^{* *}$ & $114.8388^{* *}$ & $7.2532 * *$ & $7.2532 * *$ \\
\hline$a * b$ & 14 & 24.7098 & 35.7678 & 4.6875 & 4.6875 \\
\hline$b^{*} \mathrm{~b}$ & 56 & 43.0368 & 37.8214 & 3.5792 & 3.5792 \\
\hline $\mathrm{b} 1 * \mathrm{~b}$ & 2 & 1.0010 & 8.6760 & 4.7165 & 4.7165 \\
\hline $\mathrm{b} 2 * \mathrm{~b}$ & 14 & 11.1121 & 15.8669 & 2.6657 & 2.6657 \\
\hline $\mathrm{b} 3 * \mathrm{~b}$ & 40 & 56.6778 & 46.9627 & 3.8421 & 3.8421 \\
\hline Error (Bt) & 70 & 20.46685 & 19.90639 & 2.156349 & 1.504497 \\
\hline $\mathrm{r}(\mathrm{p}-, \mathrm{wr}+\mathrm{vr})$ & & 0.94684 & 0.89749 & -0.3149 & -0.35628 \\
\hline $\mathrm{Wr}+\mathrm{Vr}$ & & $* *$ & ns & $* *$ & $* *$ \\
\hline $\mathrm{Wr}-\mathrm{Vr}$ & & ns & ns & ns & ns \\
\hline b from unity & & $*$ & ns & $\mathrm{ns}$ & ns \\
\hline $\mathrm{b}$ form 0.0 & & $* *$ & $\mathrm{~ns}$ & $* *$ & $* *$ \\
\hline
\end{tabular}

", ** Significant at 0.05 and 0.01 levels of probability; respectively, $\mathrm{b}$ from unity and from zero is the significant deviation from unity and zero; respectively, $\mathrm{r}(\mathrm{p}$, $\mathrm{wr}+\mathrm{vr})$ is the correlation between the performance of the parents and $\mathrm{Wr}+\mathrm{Vr}$, ns = not significant.

Wr - Vr was significant $(\mathrm{p} \leq 0.01)$ confirming epistatic effects of genes controlling lint \% under normal planting. The regression line under late planting (Fig. 4) intercepted the $\mathrm{Wr}$ axe under the original point (-9.9193) indicating over-dominance. The regression coefficient did not differ from unity and zero indicating the presence of epistatic effects of genes controlling lint \% under late planting. G. 86 and G. 92 were located far from the regression line out of the limiting parabola, and are the cause of epistatic effect of genes. G. 87 and G. 80 have the most dominant genes, while G. $90 \times$ Aus, G. 90 and G. 95 have the most recessive genes. The correlation between the parental performance and $\mathrm{Wr}+\mathrm{Vr}$ was positive and significant indicating that the recessive genes are increasers.

The graphical analysis of lint index (Fig. 5 and 6) under normal planting shows that, the regression coefficient $(0.8636)$ did not differ from unity and differ significantly from zero indicating no epistatic effects of genes. This is confirmed by insignificant mean squares of $\mathrm{Wr}$
- Vr (Table 4). The intercept of the regression line was very small and positive $(0.0134)$ indicating complete dominance. G. 80, G. 90, G. 92 and G. 45 are located far from the origin and carry the most recessive genes. The correlation of the parental performance and $\mathrm{Wr}$ $+\mathrm{Vr}$ was positive $(0.5754)$ but not significant indicating bidirectional dominance.

Under late planting (Fig. 6) the regression coefficient was negative and did not significantly differ from zero and unity, indicating the presence of epistatic effects of genes controlling lint index under late planting. G. 86, G. 45 and G. 92 were located below the regression line out of the limiting parabola and could be the cause of epistatic effects of genes.

The analysis of $\mathrm{Wr} / \mathrm{Vr}$ for earliness index is shown in Fig. 7 and 8. Under normal planting the regression coefficient of $\mathrm{Wr} / \mathrm{Vr}$ was significant (Table 5) from zero and unity indicating the presence of epistatic effects of genes in the inheritance of earliness index. The intercept of the regression line was positive, 
indicating partial dominance. The parental lines; G. 92, G. 90 , G. $90 \times$ Aus and G. 87 were located near the origin and carry most of the dominant genes, while G. 45 located far from the origin and carried most of recessive genes.

The correlation between the parental performance and $\mathrm{Wr}+\mathrm{Vr}$ (Table 5) was positive and significant $(\mathrm{p} \leq 0.01)$ indicating that the recessive genes were increasers. Under late planting the regression coefficient of $\mathrm{Wr} / \mathrm{Vr}$ was not significant form zero and form unity indicating epistatic effects of genes, and the regression line showed negative intercept the $\mathrm{Wr}$ axe (-9.9247) indicating over-dominance. The parental lines G. 92 and G. 86 were located under the regression line out of the limiting parabola and they were the cause of over-dominance. The distribution of the parental lines around the regression line were not consistent under the two planting conditions. Furthermore, the correlation between the parental performance and " $\mathrm{Wr}+\mathrm{Vr}$ " was positive and significant indicating that the recessive genes were increases in the inheritance of earliness index.

The graphical presentation of $\mathrm{Wr} / \mathrm{Vr}$ of days to first flowers is shown in Fig. 9 and 10. Under normal and late planting conditions the regression coefficient of $\mathrm{Wr} / \mathrm{Vr}$ was significant $(\mathrm{p} \leq 0.01)$ from zero, but not from unity indicating absence of epistatic gene effects in the inheritance of days to first flowers. The insignificant mean squares of " $\mathrm{Wr}-\mathrm{Vr}$ " (Table 5) confirmed this conclusion. The regression line intercepted the $\mathrm{Wr}$ axe near the origin showing near complete dominance. The correlation of the parental performance with $\mathrm{Wr}$ $+\mathrm{Vr}$ was negative but not significant indicating ambidirectional dominance.

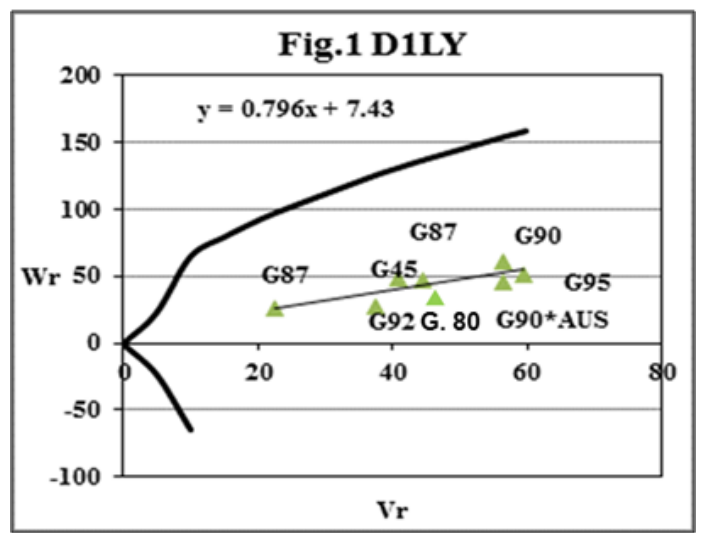

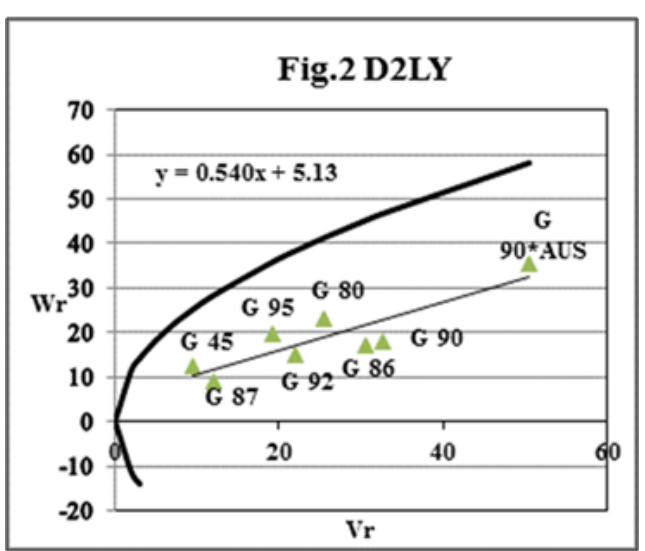
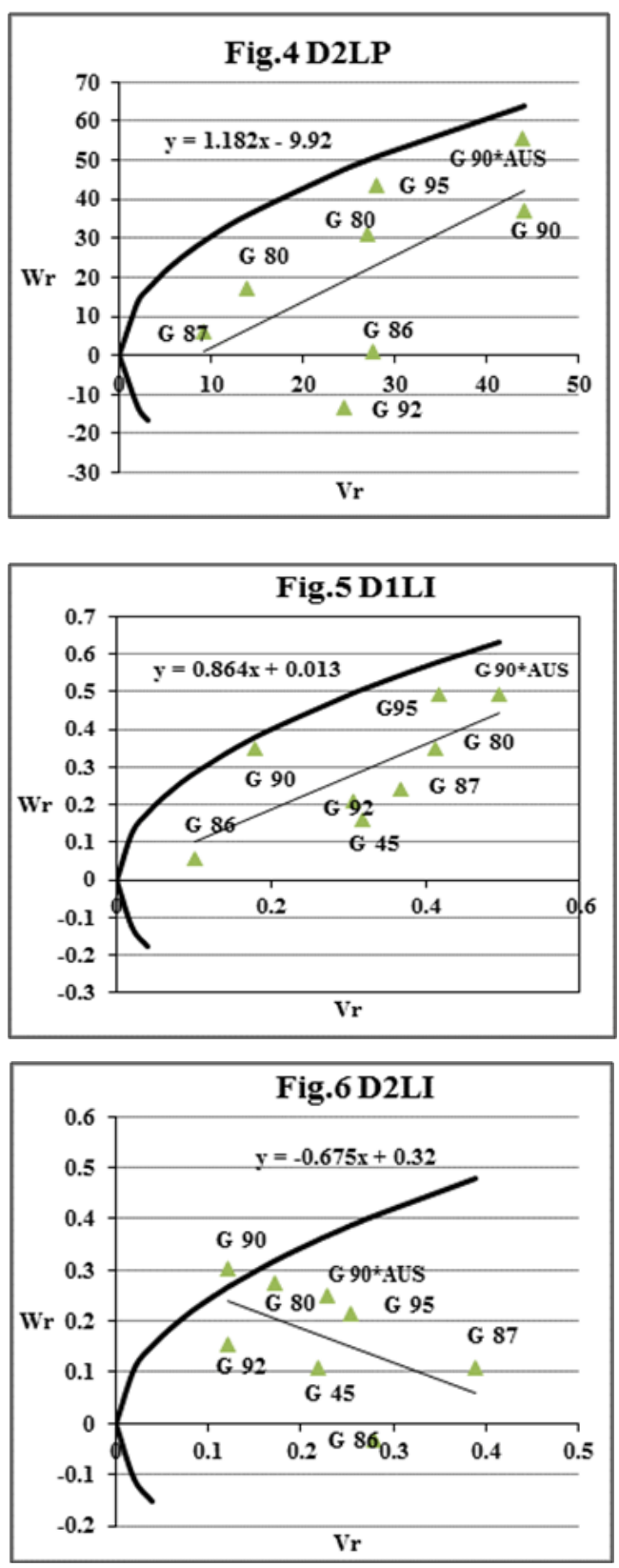

Egypt. J. Agron. 40, No. 1 (2018) 

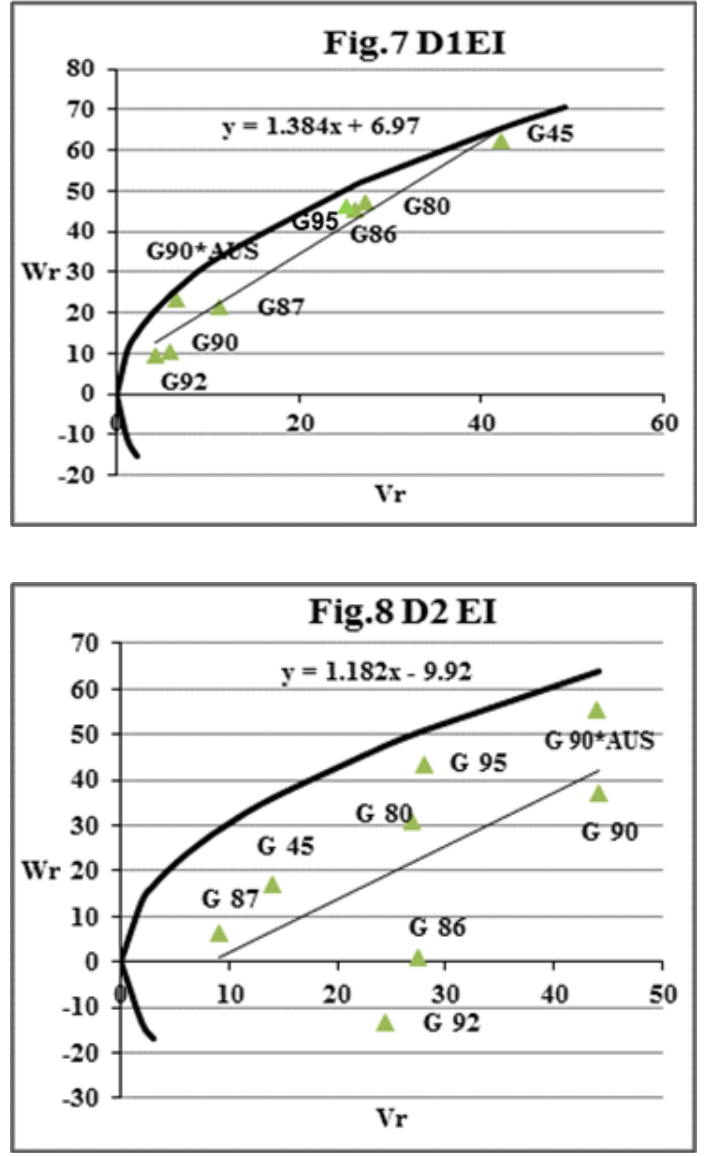
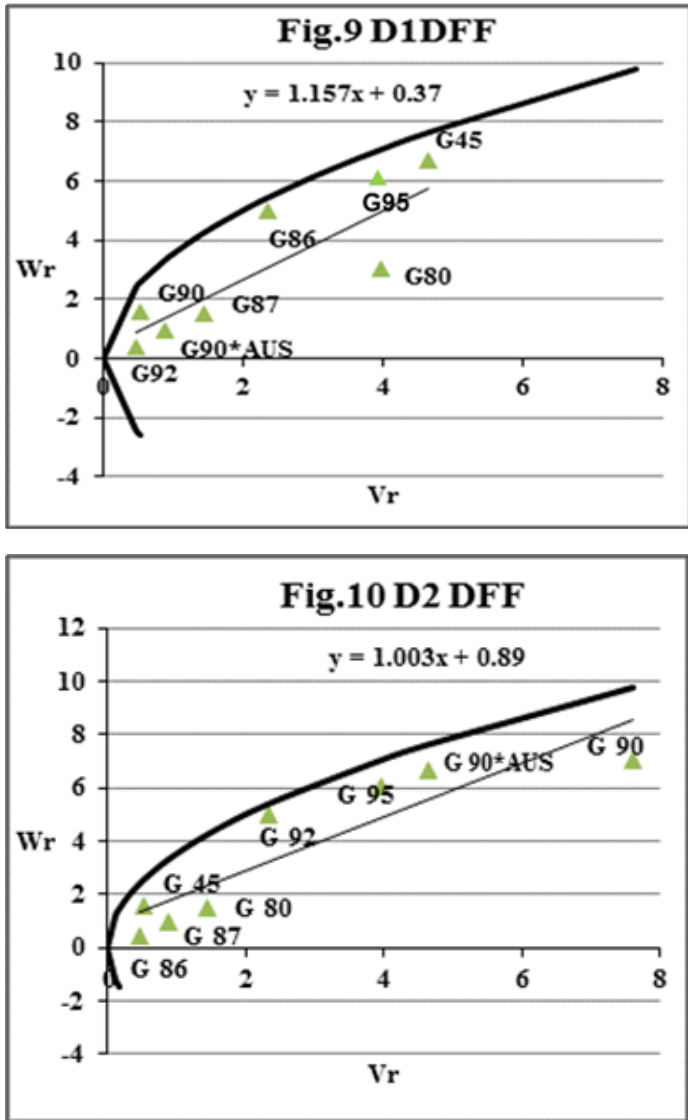

Fig. 1-10. Vr/Wr graph for all traits studied under normal (D1) and late (D2) sowing dates.

It could be concluded that the epistatic gene effects were involved in the inheritance of lint $\%$ and earliness index under the two planting conditions, and in the inheritance of lint yield/ plant and lint index under late planting. The distribution of the parental lines around the regression line, were not consistent from normal to late planting for all traits except lint yield/ plant. The recessive genes were decreasers in the inheritance of lint yield/plant and earliness index under both planting conditions and for lint $\%$ under late planting. The ambidirectional dominance of genes were found for lint index and days to first flower under both conditions, and for lint $\%$ under normal conditions. Nadeem \& Azhar (2004) indicated absence of epistasis in the inheritance of lint percentage. Mohamed et al. (2009) found non-allelic interaction in the inheritance of lint yield/plant and lint percentage under stress environmental conditions.

\section{Genetic parameters}

The genetic parameters under normal and late planting conditions are shown in Tables 6 and
7. The additive parameter "D" was significant from zero for lint yield/plant under both planting conditions. Likewise, the two dominance parameters "H1" and "H2" were significant. These results indicate that both additive and dominance effects of genes involved in the inheritance of lint yield/plant. Furthermore, the "H1" was larger than "D" under late planting indicating the importance of dominance under the stress of late planting. The parameter "H2" was less than "H1" indicating that the positive and negative alleles at the loci of this trait were not equal in proportion in the parents. Theoretically, $\mathrm{H} 2$ should be equal to or less than H1 (Hayman, 1954). These results are confirmed by the significant of "b2" in the diallel analysis of variance. The " $F$ " parameter of lint yield/plant was positive and significant $(\mathrm{p} \leq 0.01)$ indicating that the dominance alleles were more than the recessive alleles in the parents. In like manner, estimate of the ratio of dominant to recessive alleles in the parents $\left(\mathrm{K}_{\mathrm{D}} / \mathrm{K}_{\mathrm{R}}\right)$ were greater than one which indicated asymmetry of distribution of dominate and recessive genes in the parents. The estimates of UV were lower than the theoretical 
value (0.25) suggesting that positive and negative alleles were not equally distributed among the parents, and the parents seemed to carry more dominant than recessive genes as indicated by the positive significant parameter " $F$ ". The average degree of dominance $\left(\mathrm{H}_{1} / \mathrm{D}\right)^{1 / 2}$ showed nearly complete dominance. The pronounced effect of dominance was reflected in the departure of narrow from broad sense heritability; they were $0.627,0.916$ and 0.495 and 0.835 for normal and late planting, respectively (Table 6). The parental mean and the hybrids indicating the absence of hybrids vigor in lint yield/plant. The results of lint $\%$ showed the same picture of lint yield/plant.

TABLE 6. Genetic parameters of lint yield/plant, lint \% and lint Index of the diallel analysis.

\begin{tabular}{|c|c|c|c|c|c|c|}
\hline \multirow{2}{*}{ Item } & \multicolumn{2}{|c|}{ LY/P;g } & \multicolumn{2}{|c|}{ LP \% } & \multicolumn{2}{|c|}{ LI; $\mathbf{g}$} \\
\hline & D1 & D2 & D1 & D2 & D1 & D2 \\
\hline $\mathbf{D} \pm \mathrm{SE}$ & $100.79 \pm 6.593$ & $60.77 \pm 6.04$ & $10.98 \pm 0.39$ & $91.33 \pm 13.37$ & $0.737 \pm 7.972$ & $0.457 \pm 0.125$ \\
\hline $\mathrm{H} 1 \pm \mathrm{SE}$ & $101.22 \pm 15.15$ & $76.06 \pm 13.88$ & $8.37 \pm 0.905$ & $108.24 \pm 30.75$ & $0.745 \pm 0.183$ & $0.420 \pm 0.288$ \\
\hline $\mathrm{H} 2 \pm \mathrm{SE}$ & $83.79 \pm 13.18$ & $50.63 \pm 12.08$ & $7.57 \pm 0.788$ & $76.51 \pm 26.75$ & $0.701 \pm 0.159$ & $0.337 \pm 0.250$ \\
\hline $\mathrm{F} \pm \mathrm{SE}$ & $27.04 \pm 15.58$ & $49.41 \pm 14.27$ & $5.84 \pm 0.931$ & $94.32 \pm 31.61$ & $0.331 \pm 0.188$ & $0.290 \pm 0.296$ \\
\hline UV & 0.20696 & 0.16643 & 0.22595 & 0.17670 & 0.2350 & 0.2006 \\
\hline$(\mathrm{H} 1 / \mathrm{D})^{1 / 2}$ & 1.002 & 1.118 & 0.873 & 1.088 & 1.0056 & 0.9589 \\
\hline$h^{2}$ & 0.627495 & 0.49468 & 0.55147 & 0.40857 & 0.4829 & 0.3650 \\
\hline $\mathrm{H}$ & 0.91585 & 0.83512 & 0.90298 & 0.952293 & 0.8587 & 0.6114 \\
\hline $\mathrm{KD} / \mathrm{KR}$ & 1.3091 & 2.1415 & 1.8773 & 2.8045 & 1.5752 & 1.9897 \\
\hline Parents mean & 36.7041 & 28.1833 & 37,753 & 70.1933 & 6.1325 & 6.4553 \\
\hline Hybrid mean & 28.4769 & 21.6797 & 37.5330 & 67.7013 & 6.2913 & 6.2271 \\
\hline
\end{tabular}

D1 and D2; normal and late sowing dates; respectively, $\mathrm{h}^{2}$ and $\mathrm{H}$; narrow and broad sense heritability; respectively.

TABLE 7. Genetic parameters of earliness index and days of first flower of the diallel analysis.

\begin{tabular}{|c|c|c|c|c|}
\hline \multirow{2}{*}{ Item } & \multicolumn{2}{|c|}{ EI } & \multicolumn{2}{|c|}{ DFF } \\
\hline & D1 & D2 & D1 & D2 \\
\hline $\mathrm{D} \pm \mathrm{SE}$ & $81.400 \pm 7.350$ & $73.106 \pm 13.379$ & $10.381 \pm 0.726$ & $11.033 \pm 0.726$ \\
\hline $\mathrm{H} 1 \pm \mathrm{SE}$ & $-11.921 \pm 16.897$ & $58.118 \pm 30.756$ & $2.984 \pm 1.670$ & $4.777 \pm 1.670$ \\
\hline $\mathrm{H} 2 \pm \mathrm{SE}$ & $-6.444 \pm 14.700$ & $40.625 \pm 26.758$ & $1.488 \pm 1.453$ & $2.772 \pm 1.453$ \\
\hline $\mathrm{F} \pm \mathrm{SE}$ & $29.306 \pm 17.368$ & $66.979 \pm 31.613$ & $7.260 \pm 1.716$ & $8.238 \pm 1.716$ \\
\hline UV & 0.1351 & 0.1747 & 0.1247 & 0.1450 \\
\hline$(\mathrm{H} 1 / \mathrm{D})^{1 / 2}$ & 0.3826 & 0.8916 & 0.5361 & 0.6580 \\
\hline$h^{2}$ & 0.5527 & 0.2820 & 0.4772 & 0.5220 \\
\hline $\mathrm{H}$ & 0.5145 & 0.5245 & 0.5541 & 0.6727 \\
\hline $\mathrm{KD} / \mathrm{KR}$ & 2.7763 & 3.1133 & 4.7498 & 3.6228 \\
\hline Parents mean & 69.9691 & 70.1933 & 72.7916 & 72.7916 \\
\hline Hybrids mean & 67.6438 & 67.7013 & 73.3452 & 73.3452 \\
\hline
\end{tabular}

D1 and D2; normal and late sowing dates; respectively, $\mathrm{h}^{2}$ and $\mathrm{H}$; narrow and broad sense heritability; respectively.

The results of lint index (Table 6) under normal planting indicated that the additive parameter " $\mathrm{D}$ " was not significant from zero, but significant ( $\mathrm{p} \leq$ 0.01 ) under late planting. Under normal planting UV $(0.235)$ was very close the theoretical value (0.25) indicating equal distribution of dominant and recessive genes in the parents. However, the
"F" parameter was positive but not significant from zero, and the $\left(\mathrm{K}_{\mathrm{D}} / \mathrm{K}_{\mathrm{R}}\right)$ was larger than one. The mean squares of " $b_{2}$ " (Table 4) was significant. These results indicate that lint index under normal planting mainly controlled by dominance gene effects, the dominant genes were more than the recessive genes and the dominance nearly complete. The larger effects 
of dominance than additive were reflected in the departure of narrow sense $(0.4829)$ form broad sense heritability $(0.8587)$. The parental mean was near the hybrids mean indicating very small hybrid vigor. On the other hand, lint index under late planting was mainly controlled by additive genes and the parameters of dominance; H1 and H2 were not significant.

The earliness characters; earliness index and days to first flowers were mainly controlled by additive genes (Table 7), in which the additive parameter " $D$ " was significant $(p \leq 0.01)$ for both planting conditions. However, the dominance parameters; $\mathrm{H} 1$ and $\mathrm{H} 2$ were not significant except for days to first flowers under late planting. The "F" parameter in the two earliness traits were positive and significant differed from zero except for earliness index under normal planting indicating excess of dominant genes than recessive genes. The average degree of dominance indicated partial dominance. However, the "UV" estimates were far from the theoretical value $(0.25)$ which invalidated the values of average degree of dominance (Mather \& Jinks, 1971). Heritability estimates in broad sense of the two traits ranged from 0.5245 to 0.6727 , and narrow sense ranged from 0.2820 to 0.5527 . The differences between the parental means and the hybrid means were small indicating absence of hybrid vigor in general, but may some individual hybrids show hybrid vigor. Mohamed et al. (2009) found that $\mathrm{H}_{1}$ was larger than " $\mathrm{D}$ " under favorable and stressed environments for lint yield/plant and lint percentage. Basal \& Turgut (2005) noted similar results for earliness index and lint percentage. The study of Imran et al. (2012) and Simon et al. (2013) revealed that general combining ability effects was lower than specific combining ability effects for most traits.

\section{Reference}

Abd El-Bary, A.M.R. (2003) Triallel analysis of some quantitatively inherited traits in (Gossypium barbadense L.). Ph.D. Thesis, Fac. Agric., Mansoura Univ. Egypt.

Abd El-Bary, A.M.R., Soliman, Y.A.M., Hamoud, H.M.E. and Abou El-Yazied, M.A. (2008) Triallel analysis for yield components and fiber traits in (Gossypium barbadense L.). J. Agric.Sci., Mansoura Univ. 33(2), 1189-1201.

Abdalla, A.M.A. (2013) Joint regression and ordination analysis techniques of GXE interaction for the shortening growing season of cotton. Egypt. J. Plant Breed. 17(6), 99-116.
Abdalla, A.M.A. (2014) Factorial cross analysis of yield and earliness in Gossypium barbadense cottons grown on divergent sowing dates. Egypt. J. Plant Breed, 18(4), 607-628.

Abd-El-Haleem, M.H.S., Ehab, M.R.M. and Al-Felaly, A.M.M. (2010) Genetic analysis of yield and its components of some Egyptian cotton (Gossypium barbadense L.) varieties. World Journal of Agricultural Sciences, 6(5), 615-621.

Azhar M.T. and Khan, A.A. (2005) Combining ability analysis of seed cotton yield and its components in cotton (Gossypium hirsutum). Pak. J. Sci. Ind. Res. 48(5), 358-361.

Bange, M.P., Caton, S.J. and Milroy, S.P. (2008) Managing yields of high fruit retention in transgenic cotton (Gossypium hirsutum L.) using sowing date. Australian Journal of Agricultural Research, 59, 733-741.

Bange, M.P. and Milroy, S.P. (2004) Growth and dry matter partitioning of diverse cotton genotypes. Field Crops Research, 87(1), 73-87.

Basal, H. and Turgut, I. (2005) Genetic analysis of yield components and fiber strength in upland cotton (Gossypium hirsutum L.). Turkey. Asian, J. Plant Sci. 4(3), 293-298.

Bauer, P.J., May, O.L. and Camberato, J.J. (1998) Planting date and potassium fertility effects on cotton yield and fiber properties. J. Prod. Agric. 11, 415-420.

Boquet, D. and Clawson, E. (2009) Cotton planting date: Yield seedling survival and plant growth. Agron. J. 101(5), 1123-1130.

Darweesh, S.I.M. (2006) Genetic studies on breeding some Egyptian cotton varieties to resist pink boll worm, (Pectinophora gossypiella) (Saund). M.Sc. Thesis, Environ. Studies and Res. Inst. Ain Shams Univ. Egypt.

El- Rawi, K. and Khalafalla, A.M. (1980) Design and Analysis of Agricultural Experiments. El Mousel Univ., Iraq

El-Refaey, R.A. and El-Razek, U.A.A. (2013) Generation mean analysis for yield, its components and quality characteristics in four crosses of Egyptian cotton (Gossypium barbadense L.). Asian Journal of Crop Science, 5(2), 153-166.

Esmail, R.M., Hendawy, F.A., Rady, N.S. and Hamid, A.M. (1999) Genetic studies on yield and yield components in inter and two intra specific crosses of cotton. Egyptian J. Agron. 21, 37-51.

Fischer, R.A. and Maurer, R. (1978) Drought resistance in spring wheat cultivars. Part 1: Grain yield response. Augt J. Agric. Res. 29, 897-912. 
Hajazi, M.Z.I., Shakeel, A., Farooq, J., Mahmood, A., Saeed, A., Saleem, M.F. and Azhar, M.T. (2014) Genetic basis for earliness and yield contributing traits in cotton (Gossypium hirsutum L.). J. Agric. Res. 52 (3), 293-302.

Hayman, B.I. (1954) The theory and analysis of diallel crosses. Genetics, 39, 789-809.

Hayman, B.I. (1958) The theory and analysis of diallel crosses II. Genetics, 43, 63-85.

Imran, M., Shakeel, A., Azhar, F.M., Farooq, J., Saleem, M.F., Saeed, A., Nazeer, W., Riaz, M., Naeem, M. and Javaid, A. (2012) Combining ability analysis for within-boll yield components in upland cotton (Gossypium hirsutum L.). Genet. Mol. Res. 11(3), 2790-2800.

Iqbal, M.Z. and Khan, M.A. (1996) Effectiveness of additive dominance for seed and lint indices in Gossypium hirsutum L. Pak. Cotton, 40, 64-79.

Jinks, J.L. (1956) The $\mathrm{F}_{2}$ back cross generation from a set of diallel crosses. Heredity, 10, 1-30.

Jinks, J.L. and Hayman, B.I. (1953) The analysis of diallel crosses of Nicotiana rustica varieties. Maize Genet. Newsletter, 27, 48-54.

Khan, A.A., Khan, M.A. and Aziz, K. (1995) Diallel analysis of some agronomic characters in Gossypium hirsutum L. J. Agric. Res. 33, 403-12.

Kumar, K., Ashokkumar, K. and Ravikesavan, R. (2013) Genetic effects of combining ability studies for yield and fiber quality traits in diallel crosses of Upland cotton (Gossypium hirstum L.). African J. Biotech. 13 (1), 119-126.

Lasheen, A.F., Abbas, M.A. and Abdel-Zaher, G.H. (2003) Combining ability and gene action in some cotton varieties. J. Agric. Sci., Mansoura Univ. 28(5), 3317-3323.

Laxman, S., Ganesh, M. and Pradeep, T. (2003) Triallel analysis for number of bolls per plant in Upland tetraploid cotton (Gossypium hisutum L.). Indian J. Genet. Plant Breed. 63(3), 273-274.

Luckett, D.J. (1989) Diallel analysis of yield components, fiber quality and bacterial blight resistance using spaced plants of cotton. Euphytica, 44, 11-21.

Mahdy, E.E. (1982a) Genetic parameters under two planting densities in G. barbadense L. 1. Lint yield, number of bolls/plant and boll weight. Assiut $J$. Agric. Sci. 13(6), 195-207.

Mahdy, E.E. (1982b) Genetic parameters under two planting densities in G. barbadense L. 11. Lint percent, lint index and seed index. Assiut J. Agric. Sci. 13(6), 209-223.

Mather, K. and Jinks, J.L. (1971) "Introduction to
Biometrical Genetics". Cornell University Press, New York, pp. 231.

Memon, M.E.J., Kumbhar, M.B., Rind, M.I., Keerio, M and Memon, S. (2016) Combining ability estimates for yield and fiber quality parameters in Gossypium hirsutum L. Hybrids. J. Basic \& Applied Sciences 12, 53-58.

Mohamed, G.I.A., Abd-El-Halem, S.H.M. and Ibrahim, E.M.A. (2009) A genetic analysis of yield and its components of Egyptian cotton (Gossypium barbadense L.) under divergent environments. American-Eurasian J. Agric. Environ. Sci. 5(1), 05-13.

Mukhtar, M.S., Khan, T.M. and Khan, A.S. (2000) Genetic analysis of yield and yield components in various crosses of cotton (Gossypium hirsutum L.). Int. J. Agric. Biol. 2, 258-60.

Nadeem, K. and Azhar, F.M. (2004) Genetic analysis of seed cotton yield and its components in Gossypium hirsutum L. Int. J. Agric. Biol. 6(5), 865-868.

Patil, A.J., Meshram, L.D. and Sakhare, S.B. (2005) Triallel analysis for seed cotton yield in hirsutum cotton. J. Maharashtra Agric. Univ. India, 30(1), 15-18.

Pettigrew, W.T. and Meredith, W.R. (2009) Seed quality and planting date effects on cotton lint yield, yield components, and fiber quality. JCS, 13, 37 .

Raza, M.M., Munawar, M., Hammad, G., Aslam, R., Habib, S. and Latif, A. (2013) Genetic analysis of some metric plant traits in Upland cotton (Gossypium hirsutum L.) through hybridization. Universal. J. Plant Sci. 1(1), 1-7.

Simon, S.Y., Kadams, A.M. and Aliyu, B. (2013) Combining ability analysis in F1 hybrids of cotton (Gossypium species.) by diallel method in northeastern Nigeria. Greener J. Agric. Sci. Nigeria, 3(2), 90-96.

Soomro, Z.A., Larik, A.S., Kumbhar, M.B. and Khan, N.U. (2006) Expression of heterosis in the F1 generation of a diallel cross of diverse cotton genotypes. Sarhad, J. Agric., Pak. 22(3), 427-431.

Steel, R.G.D. and Torrie, J.H. (1980) "Principle and Procedures of Statistics. A Biometrical Approach" $2^{\text {nd }}$ ed., McGraw-Hill Book Company, New York. U.S. A.

Waqar, I.I.A., Khan, A.I., Khan, S.S., Shah, M. and Afzal, M. (2015) Genetic analysis of morphological traits in Upland cotton (Gossypium hirsutum L.). Sci. Letters, 3 (2), 57-61.

(Received 25 / 9 /2017; accepted $11 / 3$ /2018) 
التحليل الوراثي للتبكير ومحصول القطن الثعر ومكوناته تحت مواعيد الزراعة العادية والمتأخرة في القطن المصري التير ومري

قعين" السيد مهلى، عاطف ابوالوفا احمد، جمال حسين عبدالظاهر"، محمد عبد العزيز سيد و محمد جمال

أجري هذا العمل لدراسة تأثير ميعاد الزر اعة على الأداء في القطن المصري و الحساسية للبيئة، كذلك دراسة

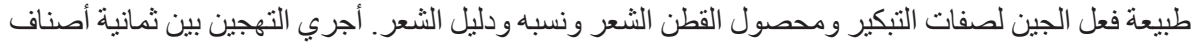

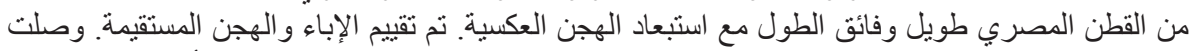

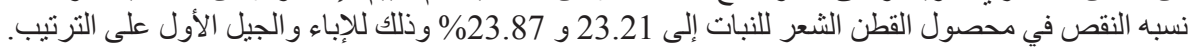

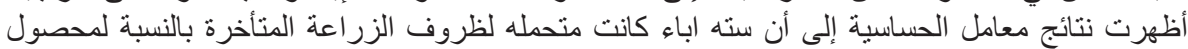

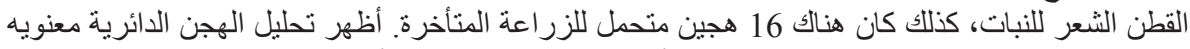

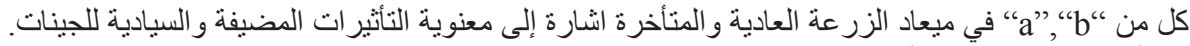

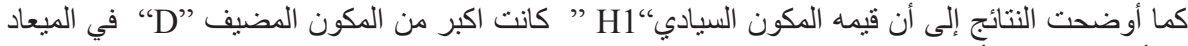

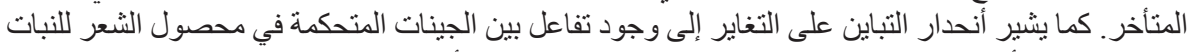

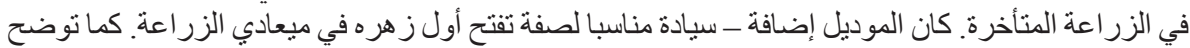

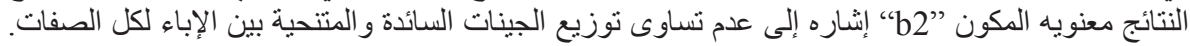

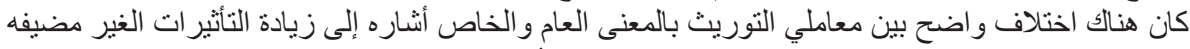

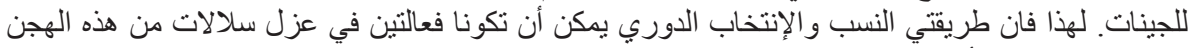
مناسبه للزر اعة المتأخرة تحت الظروف الفر المصرية. 